\title{
Lack of correlation between haemagglutination and adherence to epithelial cells in Yersinia pseudotuberculosis
}

\author{
Y. KAWAOKA,* T. MITANI, K. HOSHINA, K. OTSUKI and M. TSUBOKURA \\ Department of Veterinary Microbiology, Faculty of Agriculture, Tottori University Tottori-shi, Tottori 680, Japan
}

\begin{abstract}
Summary. Yersinia pseudotuberculosis was examined for its haemagglutinating activity and adherence to cultured epithelial cells (HEp-2) in relation to possession of a virulence $(\mathrm{VW})$ plasmid and to growth conditions. VW-lacking $\left(\mathrm{VW}^{-}\right)$bacteria were isolated from ten $\mathrm{VW}^{+}$strains of each serovar which, after they were grown on CFA plates at $37^{\circ} \mathrm{C}$, agglutinated the erythrocytes from five different species. In contrast to the bacteria possessing the plasmid $\left(\mathrm{VW}^{+}\right)$half of the $\mathrm{VW}^{-}$bacteria, grown on CFA plates at $37^{\circ} \mathrm{C}$, did not agglutinate any of the erythrocytes used and the other half agglutinated only human erythrocytes. Furthermore, when grown on CFA plates at $25^{\circ} \mathrm{C}$, neither $\mathrm{VW}^{+}$nor $\mathrm{VW}^{-}$bacteria showed a haemagglutinating activity. When the bacteria were grown in CFA broth, only two strains grown at $25^{\circ} \mathrm{C}$ did not agglutinate any of the erythrocytes tested. The $\mathrm{VW}^{+}$and $\mathrm{VW}^{-}$bacteria of the remaining strains, grown either at $25^{\circ} \mathrm{C}$ or $37^{\circ} \mathrm{C}$, showed relatively high haemagglutinating activity. Adherence to $\mathrm{HEp}-2$ cells did not correlate with haemagglutinating activity in $Y$. pseudotuberculosis; the $\mathrm{VW}^{+}$bacteria grown at $37^{\circ} \mathrm{C}$ adhered to $\mathrm{HEp}-2$ cells more efficiently than either the $\mathrm{VW}^{-}$derivatives or the $\mathrm{VW}^{+}$bacteria grown at $25^{\circ} \mathrm{C}$, regardless of the growth medium. These results indicate that some of the haemagglutinins detected on $Y$. pseudotuberculosis are not involved in the adherence to HEp-2 cells.
\end{abstract}

\section{Introduction}

Several haemagglutinins and cell surface appendages in Yersinia spp. have been detected (Maclagan and Old, 1980; Kapperud and Lassen, 1983; Skurnik, 1984; Kapperud et al., 1985a). The first haemagglutinin associated with fimbriae morphologically similar to the type I fimbriae of other enterobacteria was detected in non-pathogenic Yersinia spp. (Maclagan and Old, 1980; Skurnik, 1984) and $Y$. pseudotuberculosis (Skurnik, 1984). This haemagglutinin was expressed when the bacteria were grown at $25^{\circ} \mathrm{C}$, but not at $37^{\circ} \mathrm{C}$, and agglutinated the erythrocytes from various animal species. A second type of haemagglutinin was detected in $Y$. enterocolitica serovar O10 and was associated with the presence of fimbriae on the cell surface (Aleksic et al., 1976; Maclagan and Old, 1980). This haemagglutinin agglutinated only chicken erythrocytes. The expression of the haemagglutinin was independent of the growth temper-

Received 2 Mar. 1987, accepted 27 May 1987.

* Present address: Department of Virology and Molecular Biology, St Jude Children's Research Hospital, 332 N. Lauderdale, P.O. Box 318, Memphis, TN 38101, USA. ature. A third type of haemagglutinin has been detected only in pathogenic $Y$. enterocolitica and $Y$. pseudotuberculosis strains and was associated with fine fibrillae on the cell surface (Lachica et al., 1984; Kapperud et al., 1985a). The expression of the haemagglutinin was highly restricted; it was detected when the bacteria were grown in tissue culture media at $37^{\circ} \mathrm{C}$ but not in brain heart infusion broth nor at $25^{\circ} \mathrm{C}$ in any culture medium.

The virulence of Yersinia spp. has been associated with a $(40-50) \times 10^{6}$-mol. wt plasmid (VW plasmid) (Gemski et al., 1980a and $b$; Ferber and Brubaker, 1981). This plasmid is associated with several virulence-associated characteristics of Yersinia spp: production of VW antigens (Ferber and Brubaker, 1981; Straley and Brubaker, 1981 and 1982) and specific outer-membrane proteins (Portnoy et al., 1981; Bolin et al., 1982); cytotoxicity (Portnoy et al., 1981; Vesikari et al., 1981); low LD50 for mice (Gemski et al., 1980a; Portnoy et al., 1981); $\mathrm{Ca}^{2+}$ dependent growth at $37^{\circ} \mathrm{C}$ (Gemski et al., 1980a; Portnoy and Falkow, 1981); and autoagglutination (Laird and Cavanaugh, 1980; Vesikari et al., 1981).

In this paper, we show that some of the haemagglutinating activity does not necessarily 
correlate with the ability to adhere to epithelial cells in Y.pseudotuberculosis.

\section{Materials and methods}

\section{Bacteria}

A total of 61 strains of $Y$.pseudotuberculosis of various serovars and origins shown in table I was examined. The $\mathrm{VW}^{-}$derivatives were obtained as $\mathrm{Ca}^{2+}$-independent derivatives selected on magnesium oxalate agar plates which consisted of Trypticase Soy Broth (BBL, USA), 20 $\mathrm{mM} \mathrm{MgCl} 2,20 \mathrm{mM}$ sodium oxalate, and agar (Nakarai, Kyoto, Japan) $1.5 \%$ (Higuchi and Smith, 1961).

\section{Media}

CFA broth was prepared according to the method of Evans et al. (1977): it comprised Casamino acids (Difco, USA) $1 \%$, Yeast extract (Daigo, Osaka, Japan) $0.15 \%$, $\mathrm{MgSO}_{4} 0.005 \%$, and $\mathrm{MnCl}_{2} 0.0005 \%$. Yeast extract (YE) broth consisted of meat extract (Mikuni, Tokyo, Japan) $2 \%$, Polypepton (Daigo) $1.5 \%$, and Yeast extract $1.5 \%$. CFA and YE agar plates were prepared by adding agar at a concentration of $1.5 \%$ to CFA and YE broths, respectively. Nutrient broth and nutrient agar plates were prepared as described previously (Kawaoka et al., 1983). Heart infusion broth and Eagle's Minimal Essential Medium (MEM) were purchased from Nissui (Tokyo, Japan).

\section{Plasmid DNA isolation}

Plasmid DNA was isolated by the method of Portnoy et al. (1981).

\section{Haemagglutination ( $H A$ ) test}

Screening of HA positive strains was performed as described by Maclagan and Old (1980). The bacterial suspension $\left(0 \cdot 1 \mathrm{ml}, 10^{9}\right.$ bacteria) was mixed with $0.1 \mathrm{ml}$ of erythrocyte $1 \%$ suspension in a test tube $(12 \times 105 \mathrm{~mm})$. After incubation for $1 \mathrm{~h}$ at $37^{\circ} \mathrm{C}$, HA was read.

Titration of the HA activity was performed as follows; the concentration of bacteria was adjusted with PBS to give $\mathrm{E}_{600} 1.4$ at a 1 in 20 dilution. After serial two-fold dilution, $25 \mu \mathrm{l}$ of the bacterial suspension was mixed with $50 \mu \mathrm{l}$ of erythrocyte $1.5 \%$ suspension. HA was read after incubation for $1 \mathrm{~h}$ at $37^{\circ} \mathrm{C}$. Each strain was tested with the erythrocytes from man (blood groups $\mathrm{A}, \mathrm{AB}, \mathrm{B}, \mathrm{O}$ ), guinea pig, sheep, cow, and chicken.

The HA inhibition tests in the presence of monosaccharides were performed as follows: the bacterial suspension $(25 \mu \mathrm{l})$ containing 4 HA units $(1 \mathrm{HA}$ unit $=$ the smallest amount of haemagglutinin that gives complete haemagglutination in the HA test system described above) was mixed with $25 \mu \mathrm{l}$ of monosaccharide $5 \%$ solution. After incubation for $1 \mathrm{~h}$ at $37^{\circ} \mathrm{C}, 50 \mu \mathrm{l}$ of erythrocyte $1 \%$ suspension was added to it and incubated for $1 \mathrm{~h}$ at $37^{\circ} \mathrm{C}$. Phosphate-buffered saline (PBS) $(0.01 \mathrm{M}$,

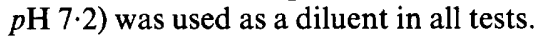

\section{Tissue culture infection}

The procedure used was a modification of the method of Lee et al. (1981). HEp-2 cells were grown in $5 \mathrm{ml}$ of MEM containing newborn calf serum $5 \%$ on $22-\mathrm{mm}^{2}$ cover slips in 70-mm diameter petri dishes. HEp- 2 cells were grown at $37^{\circ} \mathrm{C}$ in a $\mathrm{CO}_{2} 5 \%$ atmosphere. Before infection, the monolayers (approximately $10^{6}$ cells/dish) were washed three times with PBS. They were then infected with $10^{8}$ bacterial cells. After $90 \mathrm{~min}$, the cover slips were rinsed with PBS, fixed in methanol for $5 \mathrm{~min}$, and stained with Giemsa stain for $15 \mathrm{~min}$. The number of bacteria adhering to the epithelial cells was counted by light microscopy $(\times 1000)$. In each experiment, 50 cells were examined.

\section{Cell-surface hydrophobicity}

Cell-surface hydrophobicity was determined by the latex particle agglutination (LPA) test of Lachica and Zink (1984b). A 1 in 100 dilution of latex particle suspension $(0.81 \mu \mathrm{m}$ diameter, Difco) was mixed with bacteria on a glass side. A positive reaction was indicated by immediate agglutination.

\section{Electronmicroscopy}

The bacteria were negatively stained with uranyl acetate $0.5 \% \mathrm{w} / \mathrm{v}$ as described previously (Kawaoka $e t$ $a l ., 1982)$ and were examined for the presence of cellsurface appendages with a Hitachi $\mathrm{H}-500$ transmission electronmicroscope at a gun voltage of $75 \mathrm{kV}$.

\section{Results}

\section{Haemagglutination}

A total of 61 strains of $Y$. pseudotuberculosis of different serovars and origins (table I) was examined for haemagglutinating activity. All strains grown on CFA plates at $37^{\circ} \mathrm{C}$ agglutinated erythrocytes from at least one of five different species of animal. Approximately half of the strains grown at $25^{\circ} \mathrm{C}$ on CFA plates showed HA activity only with guineapig, cow, or sheep erythrocytes.

The haemagglutinin of $Y$. pseudotuberculosis was further characterised with 10 representative strains of different serovars which agglutinated all erythrocytes tested and were all VW-plasmid positive. To examine the effect of the presence of the VW plasmid on HA activity, the $\mathrm{VW}^{-}$derivatives of these strains were isolated. The presence and absence of the plasmid were confirmed by extraction of the plasmid DNA. When grown at $25^{\circ} \mathrm{C}$ on 
Table I. Origins and serovars of Y.pseudotuberculosis

\begin{tabular}{|c|c|c|c|c|c|c|c|c|c|c|c|c|c|c|}
\hline \multirow{2}{*}{$\begin{array}{l}\text { Origin } \\
\text { of strain }\end{array}$} & \multicolumn{14}{|c|}{ Number of strains of $Y$. pseudotuberculosis serovar* } \\
\hline & $1 \mathrm{a}$ & $1 b$ & $2 a$ & $2 b$ & $2 \mathrm{c}$ & 3 & $4 a$ & $4 b$ & $5 a$ & $5 b$ & 6 & 7 & 8 & total \\
\hline Man & & 2 & 4 & 1 & 3 & 1 & & 2 & 2 & 2 & 1 & & & 18 \\
\hline Rabbit & 1 & & 1 & $i$ & & 1 & & & & 2 & 1 & & & 7 \\
\hline Guinea-pig & 1 & & & & & & & & & & 3 & & & 4 \\
\hline Rat & & & & & & & 2 & & & & & & 1 & 3 \\
\hline Dog & & 1 & & 1 & 1 & & 2 & 1 & 1 & & & 1 & & 8 \\
\hline Monkey & & 1 & & & & & & 1 & & & & & & 2 \\
\hline Cow & & & & 1 & & & & & & & & & & 1 \\
\hline Cat & & & & I & 1 & 1 & & 1 & & & & & & 4 \\
\hline Pig & & & & & & 6 & & & & & & & & 6 \\
\hline Duck & & & & & & & & & 1 & & & & & 1 \\
\hline Pigeon & & & 1 & & & & & & & & & & & 1 \\
\hline Unknown & 2 & & & & & & 1 & & & & 3 & & & 6 \\
\hline Total & 4 & 4 & 6 & 5 & 5 & 9 & 5 & 5 & 4 & 4 & 8 & 1 & 1 & 61 \\
\hline
\end{tabular}

* The serovars were as defined by Tsubokura et al. (1984).

CFA agar plates, none of the strains agglutinated any erythrocytes tested (table II). All of the $\mathrm{VW}^{+}$ strains grown at $37^{\circ} \mathrm{C}$ on CFA plates showed relatively strong $\mathrm{HA}$ activity (table II). Half of the $\mathrm{VW}^{-}$derivatives grown on CFA plates at $37^{\circ} \mathrm{C}$ did not show HA activity with any of the erythrocytes tested, whereas the other half of the $\mathrm{VW}^{-}$derivatives did not show HA activity with erythrocytes from cow, chicken, guinea-pig, and sheep but retained activity with those from man (table II).

When the bacteria were grown in CFA broth, the majority of the strains ( 8 out of 10 ) showed HA activity regardless of the presence or absence of the VW plasmid, though the cells grown at $37^{\circ} \mathrm{C}$ showed higher HA activity than the cells grown at $25^{\circ} \mathrm{C}$ (table II). Only two strains showed no HA

Table II. HA activity of $Y$. pseudotuberculosis strains grown on CFA agar and in CFA broth at $25^{\circ} \mathrm{C}$ and $37^{\circ} \mathrm{C}^{*}$

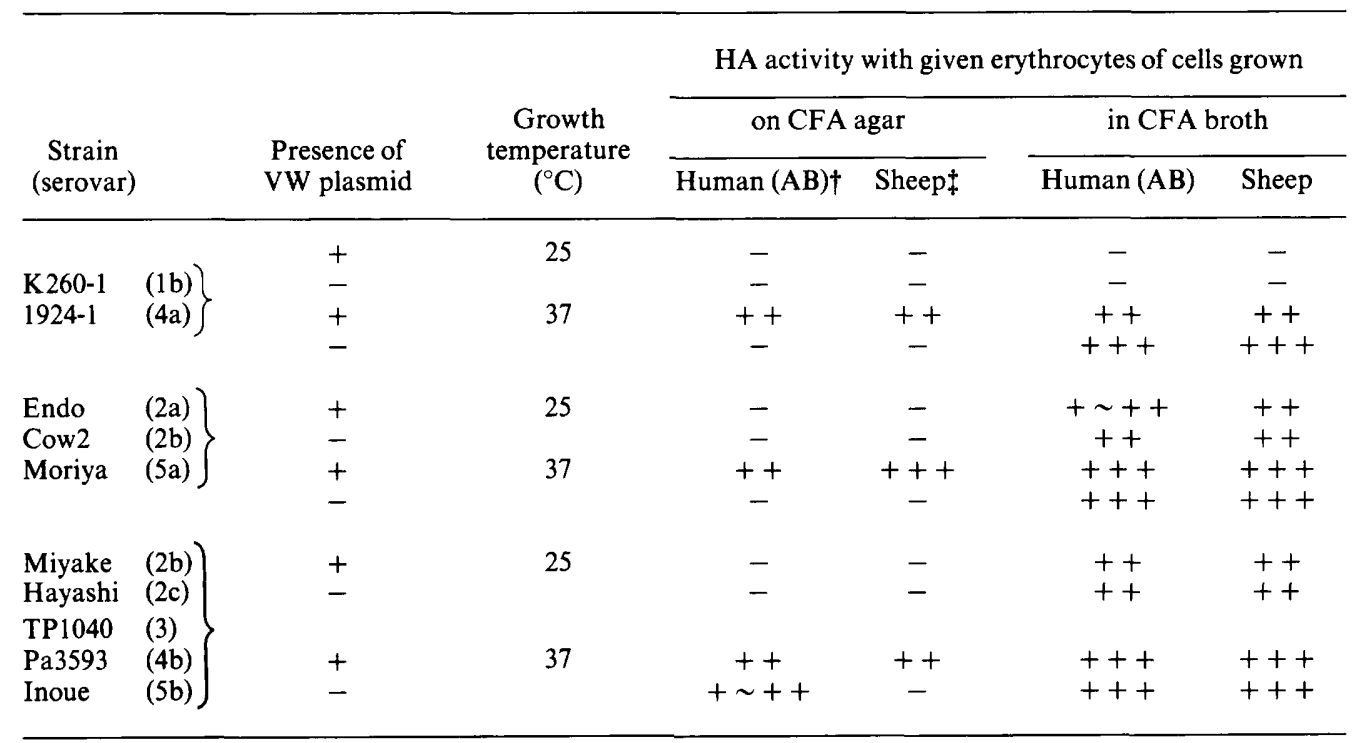

$-=<2$ units of HA activity; $+=1-8$ units; $++=16-64$ units; $+++=\geqslant 128$ units.

* The bacteria were tested after cultivation for 4 days.

† Similar results were obtained with human A, B, and $O$ erythrocytes.

‡ Similar results were obtained with cow, guinea-pig, and chicken erythrocytes. 
activity when grown at $25^{\circ} \mathrm{C}$. The dramatic loss of $\mathrm{HA}$ activity, detected in the $\mathrm{VW}^{-}$derivatives grown on CFA plates, was not observed in the cells grown in CFA broth.

Different growth media were examined for expression of the haemagglutinin of $Y$. pseudotuberculosis with both $\mathrm{VW}^{+}$and $\mathrm{VW}^{-}$bacteria of the 10 representative strains. The extent to which the media supported the expression of $\mathrm{HA}$ was as follows: CFA broth $>$ YE broth $>$ heart infusion broth $>$ nutrient broth. There was no HA observed with the cells grown in MEM containing $10 \%$ newborn calf serum at $37^{\circ} \mathrm{C}$ nor at $25^{\circ} \mathrm{C}$, which is contrary to previous findings (Kapperud et al., 1985b).

All monosaccharides detected in animals (galactose, glucose, mannose, fucose $\mathrm{N}$-acetyl galactosamine, $\mathrm{N}$-acetyl glucosamine, and $\mathrm{N}$-acetyl or $\mathrm{N}$ glycolyl neuraminic acid) were tested for their inhibitory activity to HA by $Y$. pseudotuberculosis. No HA inhibition was detected by any of the monosaccharides tested.

Stability of the haemagglutinin of $Y$. pseudotuberculosis to heat treatment was examined. The cells grown on CFA agar plates retained $\mathrm{HA}$ activity after incubation for $30 \mathrm{~min}$ at $65^{\circ} \mathrm{C}$ but lost $\mathrm{HA}$ activity after incubation at $100^{\circ} \mathrm{C}$ for $10 \mathrm{~min}$, whereas the haemagglutinin of the cells grown in CFA broth was heat labile; these bacteria lost HA activity after incubation for $10 \mathrm{~min}$ at $65^{\circ} \mathrm{C}$.

The results indicate that $\mathrm{HA}$ activity is commonly detected in $Y$. pseudotuberculosis and that the presence of the VW plasmid is associated with HA activity when the bacteria are grown on CFA plates at $37^{\circ} \mathrm{C}$, whereas the effect of the VW plasmid on HA activity is not observed when the bacteria are grown in CFA broth.

\section{Adherence to $\mathrm{HEp}-2$ cell}

To examine the correlation between HA activity and ability of the bacteria to adhere to epithelial cells, the effects of growth conditions and the presence of the VW plasmid on the adhesion of $Y$. pseudotuberculosis were examined with HEp-2 cells. In all strains, the $\mathrm{VW}^{+}$parents grown at $37^{\circ} \mathrm{C}$ had higher adhesive activity than did the $\mathrm{VW}^{-}$derivatives or the $\mathrm{VW}^{+}$bacteria grown at $25^{\circ} \mathrm{C}$ (table III). The HA activity of $Y$. pseudotuberculosis did not correlate with adhesion of the bacteria to HEp2 cells; in spite of the fact that most $\mathrm{VW}^{-}$ derivatives grown in CFA broth showed as much $\mathrm{HA}$ activity as the $\mathrm{VW}^{+}$parents did, the adhesive activity of these strains to HEp-2 cells was markedly reduced when the VW plasmid was lost. The difference in adhesive activity between the cells grown in CFA broth and those grown on CFA plates was not so prominent as the difference in the HA activity.

The results indicate that the VW plasmid of $Y$. pseudotuberculosis encodes the factor(s) involved in the adherence to HEp-2 cells, and that some of the haemagglutinin expressed on the bacterial cells grown in CFA broth at $37^{\circ} \mathrm{C}$ did not mediate adhesion to HEp-2 cells.

\section{Cell-surface hydrophobicity of $Y$. pseudotuberculosis}

Cell-surface hydrophobicity was examined by the method of Lachica and Zink (1984b) with latex particles. All $\mathrm{VW}^{+}$strains were LPA positive when grown at $37^{\circ} \mathrm{C}$ either on CFA plates or in CFA broth, whereas most of the strains did not show LPA when they were grown at $25^{\circ} \mathrm{C}$. On the other hand, most $\mathrm{VW}^{-}$derivatives did not show LPA in any growth condition.

The results indicate that the cell-surface hydrophobicity of $Y$. pseudotuberculosis correlates with the presence of VW plasmid as has been shown in Y. enterocolitica (Lachica and Zink, 1984a) and is associated with the adhesion to HEp- 2 cells but not with HA activity.

\section{Electronmicroscopic examination}

The ten strains of $Y$. pseudotuberculosis selected for detailed examinations and their $\mathrm{VW}^{-}$derivatives were examined for cell surface appendages after growth in different conditions. Fimbriae or fibrillae were not detected on the cell surface of any strains examined.

\section{Discussion}

Haemagglutinating activity was often detected in $Y$. pseudotuberculosis in this study. The effect of the VW plasmid on expression of the haemagglutinin varied with the growth media used; the expression of the haemagglutinin correlated with the presence of the VW plasmid when the bacteria were grown on CFA agar plates but not when the bacteria were grown in CFA broth. In contrast, the adherence of $Y$. pseudotuberculosis to HEp-2 cells correlated with the presence of the VW plasmid regardless of the medium in which the bacteria were grown. These results suggest that some of the haemagglutinin detected on the $\mathrm{VW}^{-}$cells grown in CFA broth is not involved in the adherence of $Y$. pseudotuberculosis to HEp-2 cells. This is similar to the findings obtained with $Y$. enterocolitica (Old 
Table III. Adherence of Y. pseudotuberculosis to HEp-2 cells*

\begin{tabular}{|c|c|c|c|c|c|}
\hline \multirow{3}{*}{$\begin{array}{l}\text { Strain } \\
\text { (serovar) }\end{array}$} & \multirow{3}{*}{$\begin{array}{c}\text { Presence } \\
\text { of VW } \\
\text { plasmid }\end{array}$} & \multicolumn{4}{|c|}{$\begin{array}{l}\text { Mean number (SD) of adherent bacteria on a HEp-2 cell } \dagger \\
\text { when cells were grown at }\end{array}$} \\
\hline & & \multicolumn{2}{|c|}{$25^{\circ} \mathrm{C}$} & \multicolumn{2}{|c|}{$37^{\circ} \mathrm{C}$} \\
\hline & & on CFA agar & in CFA broth & on CFA agar & in CFA broth \\
\hline $\begin{array}{l}\text { K260-1 } \\
\text { (1b) }\end{array}$ & + & $\begin{array}{rr}38 & (13 \cdot 5) \\
7 & (5 \cdot 7)\end{array}$ & $\begin{array}{rr}31 & (13 \cdot 3) \\
2 & (2 \cdot 3)\end{array}$ & $\begin{array}{rr}74 & (32 \cdot 3) \\
2 & (4 \cdot 8)\end{array}$ & $\begin{array}{rr}48 & (22 \cdot 3) \\
3 & (2 \cdot 3)\end{array}$ \\
\hline $\begin{array}{l}\text { Endo } \\
(2 a)\end{array}$ & + & $\begin{array}{rr}20 & (5 \cdot 6) \\
7 & (3 \cdot 9)\end{array}$ & $\begin{array}{rr}25 & (7 \cdot 1) \\
8 & (3 \cdot 5)\end{array}$ & $\begin{array}{rr}32 & (11 \cdot 4) \\
17 & (6 \cdot 0)\end{array}$ & $\begin{array}{ll}38 & (9 \cdot 7) \\
11 & (4 \cdot 2)\end{array}$ \\
\hline $\begin{array}{l}\text { Cow2 } \\
(2 b)\end{array}$ & + & $\begin{array}{rr}37 & (16 \cdot 7) \\
9 & (7 \cdot 3)\end{array}$ & $\begin{array}{rr}37 & (13 \cdot 5) \\
8 & (6 \cdot 2)\end{array}$ & $\begin{array}{l}44(13 \cdot 1) \\
12 \quad(6 \cdot 9)\end{array}$ & $\begin{array}{lr}57 & (20 \cdot 2) \\
15 & (7 \cdot 9)\end{array}$ \\
\hline $\begin{array}{l}\text { Miyake } \\
(2 \mathrm{~b})\end{array}$ & $\begin{array}{l}+ \\
-\end{array}$ & $\begin{aligned} 18 & (7 \cdot 6) \\
4 & (3 \cdot 2)\end{aligned}$ & $\begin{aligned} 15 & (6 \cdot 1) \\
3 & (4 \cdot 2)\end{aligned}$ & $\begin{array}{lr}32 & (12 \cdot 6) \\
10 & (4 \cdot 7)\end{array}$ & $\begin{array}{rr}40 & (12 \cdot 4) \\
7 & (4 \cdot 2)\end{array}$ \\
\hline $\begin{array}{l}\text { Hayashi } \\
\text { (2c) }\end{array}$ & $\begin{array}{l}+ \\
-\end{array}$ & $\begin{array}{rr}28 & (8 \cdot 4) \\
3 & (5 \cdot 3)\end{array}$ & $\begin{array}{rr}23 & (10 \cdot 3) \\
7 & (4 \cdot 5)\end{array}$ & $\begin{array}{lr}58 & (10 \cdot 4) \\
20 & (8 \cdot 5)\end{array}$ & $\begin{array}{rr}64 & (20 \cdot 3) \\
25 & (7 \cdot 8)\end{array}$ \\
\hline $\begin{array}{l}\mathrm{TP} 1040 \\
\text { (3) }\end{array}$ & $\begin{array}{l}+ \\
-\end{array}$ & $\begin{array}{rr}31 & (8 \cdot 7) \\
9 & (3 \cdot 6)\end{array}$ & $\begin{array}{lr}43 & (10 \cdot 4) \\
16 & (6 \cdot 2)\end{array}$ & $\begin{array}{lr}80 & (28 \cdot 8) \\
26 & (7 \cdot 3)\end{array}$ & $\begin{array}{rr}73 & (16 \cdot 8) \\
21 & (7 \cdot 1)\end{array}$ \\
\hline $\begin{array}{l}1924-1 \\
(4 a)\end{array}$ & $\begin{array}{l}+ \\
-\end{array}$ & $\begin{array}{ll}28 & (9 \cdot 1) \\
10 & (4 \cdot 5)\end{array}$ & $\begin{array}{rr}33 & (14 \cdot 8) \\
2 & (2 \cdot 3)\end{array}$ & $\begin{array}{rr}45 & (15 \cdot 9) \\
15 & (7 \cdot 3)\end{array}$ & $\begin{array}{rr}40 & (15.9) \\
7 & (3.9)\end{array}$ \\
\hline $\begin{array}{l}\mathrm{Pa} 3593 \\
(4 \mathrm{~b})\end{array}$ & $\begin{array}{l}+ \\
-\end{array}$ & $\begin{aligned} 22 & (5 \cdot 9) \\
3 & (3 \cdot 1)\end{aligned}$ & $\begin{array}{ll}24 & (8 \cdot 7) \\
14 & (7 \cdot 9)\end{array}$ & $\begin{aligned} 31 & (9 \cdot 3) \\
9 & (8 \cdot 5)\end{aligned}$ & $\begin{array}{l}59(20 \cdot 0) \\
18 \quad(6 \cdot 3)\end{array}$ \\
\hline $\begin{array}{l}\text { Moriya } \\
\text { (5a) }\end{array}$ & + & $\begin{aligned} 22 & (9 \cdot 9) \\
6 & (4 \cdot 6)\end{aligned}$ & $\begin{array}{r}32 \quad(15 \cdot 1) \\
6 \quad(5 \cdot 0)\end{array}$ & $\begin{array}{l}45(12 \cdot 1) \\
11 \quad(5 \cdot 9)\end{array}$ & $\begin{array}{l}67(26 \cdot 1) \\
12 \quad(5 \cdot 3)\end{array}$ \\
\hline $\begin{array}{l}\text { Inoue } \\
(5 b)\end{array}$ & + & $\begin{aligned} 21 & (5 \cdot 0) \\
4 & (2 \cdot 9)\end{aligned}$ & $\begin{array}{rr}11 & (4 \cdot 9) \\
1 & (0 \cdot 8)\end{array}$ & $\begin{array}{ll}33 & (6.9) \\
11 & (3.9)\end{array}$ & $\begin{aligned} 33 & (7 \cdot 1) \\
5 & (3 \cdot 2)\end{aligned}$ \\
\hline
\end{tabular}

* The bacteria were tested after cultivation for 4 days.

$\dagger$ The bacteria which invaded in the cells were also included.

and Robertson, 1981); the haemagglutinins of $Y$. enterocolitica do not necessarily explain adherence to HEp-2 cells. However, we should not conclude that the haemagglutinin of $Y$.pseudotuberculosis is unimportant for $Y$. pseudotuberculosis infection, because HEp- 2 cells may not necessarily represent the cells involved in infection in vivo. Other cells should also be examined.

At least two different haemagglutinins have been reported in $Y$. pseudotuberculosis. Kapperud et al. (1985a) found a haemagglutinin and very fine fibrillae on the cell surface of $Y$. pseudotuberculosis grown in tissue culture media at $37^{\circ} \mathrm{C}$ but not at $25^{\circ} \mathrm{C}$. This haemagglutinin is associated with the presence of the VW plasmid and agglutinates only guinea-pig erythrocytes. The haemagglutinin of $Y$. pseudotuberculosis reported by Skurnik (1984) is expressed at $25^{\circ} \mathrm{C}$ either on nutrient agar or in nutrient broth and is associated with thin or thick fimbriae or both. Although these haemagglutinins differ from the one detected in the present study in their specificity for different erythrocytes, the presence of appendages on the cell surface, and the effect of the VW plasmid and growth condition, these differences could be due to slight differences in the growth conditions.

The effect of the presence of the VW plasmid on HA activity differed between the cells grown on CFA plates and in CFA broth and the stability of the haemagglutinins to heat differed between the cells grown on CFA agar plates and those grown in CFA broth. Furthermore, different HA patterns were observed when the bacteria were grown on CFA agar, showing heterogeneity of the haemagglutinin of $Y$. pseudotuberculosis. Another possibility is that the difference was a consequence of quantitative differences of the haemagglutinin in response to the different growth conditions.

The adherence of Yersinia spp. to various epithelial cells has been investigated. Some $Y$. enterocolitica adhere to epithelial cells when grown at $25^{\circ} \mathrm{C}$ but not at $37^{\circ} \mathrm{C}$ (Okamoto et al., 1980; Old 
and Robertson, 1981) and some adhere equally well after cultivation at $25^{\circ} \mathrm{C}$ or at $37^{\circ} \mathrm{C}$ (Lee et al., 1981 ; Old and Robertson, 1981). Because the $\mathrm{VW}^{-}$ derivatives showed adhesive ability with epithelial cells (Portnoy et al., 1981; Schiemann, 1981; Heesemann et al., 1983), the plasmid had not been considered to be involved in the adherence of pathogenic $Y$. enterocolitica. Heesemann et al. (1984), however, reported that non-pathogenic $Y$. enterocolitica acquired the ability to adhere to epithelial cells after acquisition of the VW plasmid from pathogenic $Y$. enterocolitica. The VW plasmid, therefore, appears to encode the factor(s) involved in the adherence of $Y$. enterocolitica to epithelial cells. Bölin et al. (1982) reported that $Y$. pseudotuberculosis grown at $25^{\circ} \mathrm{C}$ adhere to HeLa cells to a greater extent than the cells grown at $37^{\circ} \mathrm{C}$ and that the VW plasmid was not involved in this adherence. These results differ from those obtained in our study. As Bölin et al. (1982) examined only one strain, a strain similar to the one that Bölin et al. used might not have been included in our study and $Y$. pseudotuberculosis may be heterogenous in dependency of the adherence to epithelial cells on growth temperature and the presence of the VW plasmid.

Cell-surface hydrophobicity correlated with the adherence to HEp-2 cells but not with the HA activity of $Y$.pseudotuberculosis cells grown in CFA broth. Cell-surface hydrophobicity seems to originate from the specific outer-membrane proteins encoded by the VW plasmid and contributes to

\section{REFERENCES}

Aleksic S, Rohde R, Muller G, Wohlers B 1976 Examination of the envelope antigen $\mathrm{K} 1$ in Yersinia enterocolitica which was identified as fimbriae. Zentralblatt fur Bakteriologie, Parasitenkunde, Infektionskrankheiten und Hygiene I, Abteilung Originale A 234: 513-520.

Balligand G, Laroche Y, Cornelis G 1985 Genetic analysis of virulence plasmid from a serogroup 9 Yersinia enterocolitica strain: Role of outer membrane protein $\mathrm{Pl}$ in resistance to human serum and autoagglutination. Infection and Immunity 48: 782-786.

Bölin I, Norlander L, Wolf-Watz H 1982 Temperature-inducible outer membrane protein of Yersinia pseudotuberculosis and Yersinia enterocolitica is associated with the virulence plasmid. Infection and Immunity 37: 506-512.

Evans D G, Evans D J, Tjoa W S 1977 Hemagglutination of human group A erythrocytes by enterotoxigenic Escherichia coli isolated from adults with diarrhea: correlation with colonization factor. Infection and Immunity 18: 330-337.

Ferber D M, Brubaker R R 1981 Plasmid in Yersinia pestis. Infection and Immunity 31: 839-841.

Gemski P, Lazere J R, Casey T $1980 a$ Plasmid associated with pathogenicity and calcium dependency of Yersinia enterocolitica. Infection and Immunity 27: 682-685. autoagglutination in $Y$. enterocolitica (Martinez, 1983; Lachica and Zink, 1984a; Lachica et al., 1984). The haemagglutinin detected in pathogenic $Y$. enterocolitica was expressed on the cell surface of the $\mathrm{VW}^{+}$bacteria grown at $37^{\circ} \mathrm{C}$ and was, therefore, considered to confer hydrophobic property on the cells (Lachica et al., 1984a). The haemagglutinin associated with fimbriae detected in non-pathogenic $Y$. enterocolitica strains with cellsurface hydrophobicity (Kihlstrom and Magnusson, 1983). In contrast, the haemagglutinin expressed on $Y$. pseudotuberculosis grown in CFA broth did not confer hydrophobicity to the cells.

The VW plasmid encodes specific outer-membrane proteins expressed at $37^{\circ} \mathrm{C}$ but not at $25^{\circ} \mathrm{C}$. One of these proteins, $\mathrm{P} 1$, is involved in serum resistance and autoagglutination of $Y$. enterocolitica (Skurnik et al., 1984; Balligand et al., 1985). Kapperud et al. (1985a) suggested that one of these outer-membrane proteins, HMWP (probably identical to P1) was fine fibrillae and was involved in HA. There are at least eight different outermembrane proteins encoded by the VW plasmid and expressed at $37^{\circ} \mathrm{C}$ but not at $25^{\circ} \mathrm{C}$. The haemagglutinin detected on the $\mathrm{VW}^{+}$cells grown on CFA agar plates at $37^{\circ} \mathrm{C}$ could be one of these proteins. Studies are in progress to identify and purify the haemagglutinin(s) of $Y$. pseudotuberculosis detected in this study.

We thank Lisa Wilson for typing the manuscript.

Gemski P, Lazere J R, Casey T, Wohlhieter J A $1980 b$ Presence of a virulence-associated plasmid in Yersinia pseudotuberculosis. Infection and Immunity 28 : 1044-1047.

Heesemann J, Algermissen B, Laufs R 1984 Genetically manipulated virulence of Yersinia enterocolitica. Infection and Immunity 46: 105-110.

Heesemann J, Keller C, Morawa R, Schmidt N, Siemens H J, Laufs R 1983 Plasmids of human strains of Yersinia enterocolitica: molecular relatedness and possible importance for pathogenesis. Journal of Infectious Disease 147: 107-115.

Higuchi K, Smith J L 1961 Studies on the nutrition and physiology of Pasteurella pestis. VI. A differential plating medium for the estimation of the mutation rate to avirulence. Journal of Bacteriology 81 : 605-608.

Kapperud G, Lassen J 1983 Relationship of virulence-associated autoagglutination to hemagglutinin production in Yersinia enterocolitica and Yersinia enterocolitica-like bacteria. Infection and Immunity 42: 163-169.

Kapperud G, Namork E, Skarpeid H J 1985a Temperatureinducible surface fibrillae associated with the virulence plasmid of Yersinia enterocolitica and Yersinia pseudotuberculosis. Infection and Immunity 47: 561-566.

Kapperud G, Skarpeid H J, Solberg R, Bergan T $1985 b$ Outer membrane proteins and plasmids in different Yersinia 
enterocolitica serogroups isolated from man and animals. Acta Pathologica Microbiologica et Immunologica Scandinavica Section B 93: 27-35.

Kawaoka Y, Otsuki K, Tsubokura M 1982 Characteristics of Yersinia enterocolitica bacteriophages. Zentralblatt fur Bakteriologie Mikrobiologie und Hygiene I Abteilung Originale A 253: $102-109$.

Kawaoka Y, Otsuki K, Tsubokura M 1983 Growth temperaturedependent variation in the bacteriophage-inactivating capacity and antigenicity of Yersinia enterocolitica lipopolysaccharide. Journal of General Microbiology 129: 27392747.

Kihlstrom E, Magnusson K E 1983 Hemagglutinating, adhesive and physico-chemical surface properties of different Yersinia enterocolitica and Yersinia enterocolitica-like bacteria. Acta Pathologica Microbiologica et Immunologica Scandinavica Section B 91 : 113-119.

Lachica R V, Zink D L 1984a Plasmid-associated cell surface charge and hydrophobicity of Yersinia enterocolitica. Infection and Immunity 44: 540-543.

Lachica R V, Zink D L $1984 b$ Determination of plasmidassociated hydrophobicity of Yersinia enterocolitica by a latex particle agglutination test. Journal of Clinical Microbiology 19: 660-663.

Lachica R V, Zink D L, Ferris W R 1984 Association of fibril structure formation with cell surface properties of Yersinia enterocolitica. Infection and Immunity 46: 272-275.

Laird W J, Cavanaugh D C 1980 Correlation of autoagglutination and virulence of Yersiniae. Journal of Clinical Microbiology $11: 430-432$.

Lee W H, Smith R E, Damare J M, Harris M E, Johnston R W 1981 Evaluation of virulence test procedures for Yersinia enterocolitica recovered from foods. Journal of Applied Bacteriology 50: 529-539.

Maclagan R M, Old D C 1980 Hemagglutinins and fimbriae in different serotypes and biotypes of Yersinia enterocolitica. Journal of Applied Bacteriology 49 : 353-360.

Martinez R J 1983 Plasmid-mediated and temperature-regulated surface properties of Yersinia enterocolitica. Infection and Immunity 41 : 921-930.
Okamoto $\mathrm{K}$, Inoue $\mathrm{T}$, Ichikawa $\mathrm{H}$, Kawamoto $\mathrm{Y}$, Hara $\mathrm{S}$, Miyama A 1980 Adherence of Yersinia enterocolitica to mammalian epithelial cell lines. Microbiology and Immunology 24: 1013-1022.

Old D C, Robertson J 1981 Adherence of fimbriate and nonfimbriate strains of Yersinia enterocolitica to human epithelial cells. Microbiology and Immunology 25 : 993-998.

Portnoy D A, Falkow S 1981 Virulence-associated plasmids from Yersinia enterocolitica and Yersinia pestis. Journal of Bacteriology 148: 877-883.

Portnoy D A, Moseley S L, Falkow S 1981 Characterization of plasmids and plasmid-associated determinants of Yersinia enterocolitica pathogenesis. Infection and Immunity 31 : 775782.

Schiemann D A 1981 An enterotoxin-negative strain of Yersinia enterocolitica serotype $0: 3$ is capable of producing diarhea in mice. Infection and Immunity 32: 571-574.

Skurnik M 1984 Lack of correlation between the presence of plasmids and fimbriae in Yersinia enterocolitica and Yersinia pseudotuberculosis. Journal of Applied Bacteriology 56: 355363.

Skurnik M, Bölin I, Heikkinen H, Piha S, Wolf-Watz H 1984 Virulence plasmid-associated autoagglutination in Yersinia spp. Journal of Bacteriology 158: 1033-1036.

Straley S C, Brubaker R R 1981 Cytoplasmic and membrane proteins of Yersiniae cultivated under conditions simulating mammalian intracellular environment. Proceedings of the National Academy of Sciences of the USA 78: 1224-1228.

Straley S C, Brubaker R R 1982 Localization in Yersinia pestis of peptides associated with virulence. Infection and Immunity 36: 129-135.

Tsubokura M, Otsuki K, Kawaoka Y, Fukushima H, Ikemura $\mathrm{K}$ and Kanazawa Y 1984 Addition of new serogroups and improvement of the antigenic designs of Yersinia pseudotuberculosis. Current Microbiology 11 : 89-92.

Vesikari T et al. 1981 Plasmids in Yersinia enterocolitica serotypes $0: 3$ and $0: 9$ : correlation with epithelial cell adherence in vitro. Infection and Immunity 33: 870-876. 